\title{
Food security and nutrition - the Ethiopian case for action
}

\author{
Dorit Nitzan Kaluski ${ }^{1,2, *}$, Einat Ophir ${ }^{3}$ and Tilahun Amede 4 \\ 'Department of Nutrition, Public Health Services, Ministry of Health, 20 King David Street, POB 1176, Jerusalem \\ 91010, Israel: ${ }^{2}$ Department of Epidemiology and Preventive Medicine, Sackler Faculty of Medicine, Tel Aviv \\ University, Israel: ${ }^{3}$ Israel Centre for Disease Control and Public Health Services, Ministry of Health, Israel: ${ }^{4}$ African \\ Highlands Initiative, Areka Benchmark Site, Ethiopia
}

Submitted 3 July 2001: Accepted 19 0ctober 2001

\begin{abstract}
Objective: To assess the 1999-2000 food security situation and the food relief programmes in Ethiopia, and evaluate the need for a national food and nutrition policy.

Design: A systematic search of data sources from the Ethiopian Disaster Prevention and Preparedness Commission (DPPC), the Ethiopian Central Statistical Authority, the World Food Programme (WFP) and United Nations Children's Fund (UNICEF), the bibliographic database Medline and direct contacts with associations, institutions and people concerned with food security in Ethiopia.

Setting: Consultations to WFP Ethiopia.

Results: Food availability was severely restricted due to recurrent disasters such as drought, flood, war and a lack of diversity of food items. Food accessibility was limited due to a weak subsistence-agriculture-based economy, depletion of assets, absence of income diversity and a lack of alternative coping mechanisms. Food intake adequacy was rarely achieved due to food shortages, improper diet and poor sanitary conditions. There was a lack of early warning data to monitor food security indicators. Food aid programmes did not meet the requirements for food quantities and composition, and faced major obstacles in logistics and targeting of the vulnerable population.

Conclusions: Improvements in food security and the eradication of famine will require investment in sustainable projects. There is an immediate need for better planning and targeting of food aid and a national food security monitoring system. A national food and nutrition policy is recommended, focusing both on relief efforts and on underlying factors contributing to the famine.
\end{abstract}

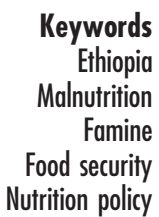

Ethiopia is one of the least developed countries in the world $^{1}$ and is the second most severely affected by malnutrition world-wide ${ }^{2}$. Food shortages in Ethiopia aggravate the already poor health of children and adults. In 1999/2000 as many as eight million people received assistance from the government, international donors and non-governmental organisations (NGOs) ${ }^{3}$. The 1994 census revealed a population of 53.5 million with over $50 \%$ of the population under 20 years old and a mean annual growth rate of $3.1 \%$ per annum ${ }^{4}$. The present population is about 65 million $^{5}$. The estimated infant mortality rate is 112.9 and under five mortality is 187.8 deaths per 1000 live births ${ }^{6}$. The life expectancy is 49.7 and 52.1 years for men and women, respectively ${ }^{4}$. The population is $86 \%$ rural and $14 \%$ urban, with an average of 49 inhabitants per square kilometre ${ }^{7}$. Women in rural regions spend most of the day carrying water, wood and infants on their back for long distances. They also participate in farming practices, mainly around the home garden. Men concentrate on agricultural work such as cultivation of crops and herding livestock ${ }^{8}$.

The low access to safe water and poor sanitation facilities lead to a high incidence of diarrhoeal diseases?. People suffer from recurrent episodes of malaria. They are vulnerable to vaccine-preventable diseases such as measles, with a reported immunisation rate of about $26.6 \%$ for children aged 12 to 23 months $^{6}$. One in $11 \mathrm{HIV}-$ positive people in the world lives in Ethiopia, with the adult rate of HIV/AIDS at the end of 1999 estimated at $10.6 \%{ }^{10}$. Nutrition in HIV/AIDS could have bi-directional effects: micronutrient deficiencies (MNDs) may increase the transmission of the disease, while HIV/AIDS patients have higher nutritional requirements ${ }^{11}$. The National Population Office states that there is one physician per 30000 people $^{12}$.

The Ethiopian economy is based on subsistence agriculture, which accounts for more than half of the gross domestic product (GDP), 90\% of exports and 80\% of 
total employment ${ }^{8}$. It is highly dependent on both the quantity and timing of the seasonal rainfall ${ }^{13}$. The agricultural sector suffers from frequent periods of drought, pest infestation and technologically limited farming practices. The government is in the process of selling off a portion of state-owned plants and implementing reform measures that are gradually liberalising the economy ${ }^{14}$.

Regional conflicts and civil strife have troubled the country for many years. The recent war between Ethiopia and Eritrea began in May 1998 and had continued, with periodic eruptions of violence, until the cease-fire agreement sponsored by the Organisation of African Unity (OAU) was signed in Algiers on 18 June 2000. Nevertheless, large populations have been displaced as a result of the conflict.

Since the 1970s there has been a series of crop failures, with exploitation of the land leading to the erosion of traditional coping mechanisms in a population already suffering from chronic poverty ${ }^{15}$. Both these critical factors exacerbated the severe effects of the 1998/99 drought. In this regard, the famine should be seen less as a consequence of a single natural disaster and more as a result of deep-rooted structural problems. Since the $1960 \mathrm{~s}$ food aid programmes have been implemented in the country. In this paper we analyse the current famine and the food aid programmes by using the conceptual framework of food and nutrition security.

\section{Methods}

In this descriptive study we assess the food aid response to Ethiopia in 1999-2000. The intervening determinants of malnutrition considered here are the components of food security. Nutritional data were used to measure the magnitude of malnutrition.

\section{Sources of data}

Secondary data were collected from official information sources and specific studies carried out in Ethiopia. Demographic, socio-economic and epidemiological data were retrieved from demographic reports of the Ethiopian Central Statistical Authority, United Nations Children's Fund (UNICEF), World Bank, Food and Agriculture Organization (FAO), World Health Organization (WHO), World Food Programme (WFP) and United States Agency for International Development (USAID) reports. Information from the Ministry of Health and the Ethiopian Disaster Prevention and Preparedness Commission (DPPC) were also utilised. Medline search and direct contacts with institutions and people concerned in food security in Ethiopia were also used.

\section{Variables}

Food security was assessed using its three dimensions: availability of safe and nutritious food, accessibility of sufficient resources (including physical access, economic, social and demographic factors affecting the ability to acquire food) and adequacy of diet, hygiene practices, water and sanitation. The magnitude of malnutrition was assessed by the prevalence rates of stunted growth and wasting and vitamin $\mathrm{A}$, iodine, iron and zinc deficiencies derived from national and localised surveys. Food relief appeals and food quantities delivered, as well as logistics, targeting and early warning system assessments, were based on reports of the DPPC, United Nations (UN) organisations and NGOs.

\section{Results}

\section{Food insecurity - the intervening cause of malnutrition and famine}

The prevalence of malnutrition in Ethiopia continues to increase, affecting primarily women and children ${ }^{16}$. The daily energy intake of the average Ethiopian was lower than the WFP minimum standard (2100 calories per day $)^{17-20}$. The most important documented forms of malnutrition in Ethiopia were protein-energy malnutrition and vitamin $\mathrm{A}$, iodine and zinc deficiencies.

Stunting and wasting rates have been among the highest in the world for children under five $e^{2,21,22}$. In 1992, the prevalence of stunting (64\%) was the third highest in the world after Bangladesh and Mauritania ${ }^{23}$. The most recent data showed that $51.1 \%$ of 10449 children were below -2 $Z$-score and $26.3 \%$ were below $-3 Z$-score for height ${ }^{6}$. The prevalence rate of underweight was $46 \%$ and the prevalence of wasting was 11\%, considerably higher than the rates observed in 1992.

The lack of data on adult malnutrition is especially important, since the commonly held view that childhood nutritional status can be used as a proxy for household nutritional risks has been questioned ${ }^{24}$. A study in Ethiopia found that it has low sensitivity and high specificity, suggesting that intra-household members may not fully share risk factors for malnutrition ${ }^{25,26}$. In the late 1980 s, $5 \%$ of women in Southern Ethiopia were found to be severely malnourished with a body mass index (BMI) lower than $16.0 \mathrm{~kg} \mathrm{~m}^{-2}$. Almost $50 \%$ of the women in that area were underweight. Only 19\% of the women had adequate weight gain $\left(0.45 \mathrm{~kg}\right.$ per week) during pregnancy ${ }^{27}$. A survey in 1996 on adult malnutrition revealed that BMI was lower than $18.5 \mathrm{~kg} \mathrm{~m}^{-2}$ in $24 \%$ of men and $27 \%$ of women, with higher rates among low-income households ${ }^{28}$. Thus, on a community level, it is clear that both children and adults are at risk for malnutrition, and are at need for Food and Nutrition Security (FNS) programmes.

Vitamin A deficiency (VAD) has been documented in Ethiopia since $1957 / 8^{29-32}$. In all surveys it appears that the highest rates were found in children residing in pastoral areas, followed by those living in grain-cropping and cash-cropping (e.g. coffee and chat) zones. A survey done in 1996 showed that 53\% of males and 26\% of 
females aged 6-72 months had night blindness and Bitot's spots, with the highest rates in those 36 to 72 months of age $^{28}$. The lowest rates were documented in areas where people consume enset (Enset ventricosum), a root plant known as 'false banana', commonly eaten with bean sauce or kale, which are rich in carotene.

Iodine deficiency disorders (IDD) are common in Ethiopia, with visible goitre rate (VGR) as high as $28 \%{ }^{22}$. Moreover, a national goitre survey done in 1981 found a mean total goitre rate (TGR) of $25.1 \%$. The mean rate was higher in highlands above $2000 \mathrm{~m}$ (33.9\%) than at lower elevations $(19.2 \%)^{33}$. Using goitre prevalence data and the epidemiological prediction model for IDD, it was estimated that in 1990 there were 59000 (1.1 per 1000) cretins in Ethiopia, and three times as many people (3.5 per 1000) showed some degree of developmental and neurological function impairment attributable to IDD $^{31}$. Salt has not been iodised since 1995. Therefore, it can be assumed that IDD rates are even higher.

The prevalence of iron-deficiency anaemia (IDA) in children has not been documented on a national basis. Some local studies have indicated that IDA is not a major public health problem, especially in areas where the highiron-content grain, teff (Eragrostis teff), is consumed as a staple food. Nevertheless, in 1968, Hovander demonstrated a high prevalence of anaemia (60\%), of which $17 \%$ was presumed to be due to iron deficiency ${ }^{34}$. The nationwide survey conducted on pregnant and lactating mothers from 1990 to 1994 indicated an overall prevalence rate of IDA of $18 \%$, with a higher prevalence in areas where inhabitants consume sorghum, followed by areas where milk, enset and barley are the staple foods (Haidar J, unpublished data). Food aid programmes in those regions may result in the replacement of teff by the distributed wheat, thereby contributing to an increased risk of iron deficiency. Helminth (particularly hookworm) infections have been shown to cause IDA. Hookworm is widespread in Ethiopia in the 800 to $1200 \mathrm{~m}$ altitude zone and humid western lowlands, even at lower elevations. Rates between 60 and 80\% were found in lowlands of Ilubabor, Kefa and Wellega and lower rates of $21-29 \%$ were found below $2000 \mathrm{~m}^{35}$.

Other MNDs in Ethiopia have been only assessed anecdotally. Still, it can be assumed that the consumption of calcium, zinc and other micronutrients is below the recommended dietary intake levels. A recent clinical trial revealed the importance of zinc supplementation to improve the growth of Ethiopian children ${ }^{36,37}$.

The different administrative regions of Ethiopia have various population densities, resources, opportunities and culinary habits, and consequently differ in many aspects of food security. About $10 \%$ of the population live in pastoral and semi-pastoral communities that occupy $60 \%$ of the land. These communities live in agriculturally marginal lowlands that are prone to frequent drought and famine. On the other hand, communities in the central highlands maintain sedentary agriculture, which is based on crops and livestock. Thus, assessments of the FNS status in the different regions are required in order to tailor food aid programmes to the Ethiopian geographic, demographic and cultural diversities.

Table 1 presents food security analyses of the different Ethiopian regions in 1999 according to availability, accessibility and adequacy and the estimated needy population in 2000 and its needs. The regional needs are variable. Some of the highest prevalence rates of malnutrition were found in the food-surplus regions of the country, indicating what is already known: food availability is only one component of food security and not the only determining factor ensuring adequate nutritional status $^{38}$. Therefore, for some regions, a short-term tailored food aid could compensate for the lack of available foods, whereas others could benefit more from health and nutrition education or agricultural assistance. Development programmes focusing on education, industrialisation, water supply, sanitation, transportation and communication are required for all of the regions.

\section{Food relief programmes 1999-2000 - facts and gaps}

The food aid programmes were analysed by comparing the appeals for food relief with the availability, accessibility and adequacy of the food aid actually delivered to the Ethiopians (food quantity and quality, logistics and targeting).

\section{Food appeals and quantities delivered}

In December 1998 the Ethiopian DPPC launched an appeal for emergency food assistance estimating the relief food needs for 1999. Subsequently, due to the almost total failure of the belg rains (short rains from February to March), together with a variety of other stressful environmental hazards (such as pest and weed infestations), the food security situation worsened. In many parts of the country the nutritional status, particularly of young children, pregnant and lactating women and the elderly, deteriorated over the course of $1999^{39}$. The appeals by the DPPC were increased in order to comply with the decline in food security. In response to the DPPC's appeal, the WFP ratified the 'Emergency Operation 6143'. Together with donors' support, 97\% of the requested quantity was met.

In mid-1999, the DPPC's Early Warning Working Group estimated higher relief food needs (based on a standard ration of $15 \mathrm{~kg}$ per beneficiary per month) than the estimates for the previous year. This was the highest request for the past eight years. In order to include the requirements of Ethiopians displaced due to the Ethiopia/Eritrea border conflict and of other displaced individuals, WFP approved the 'Emergency Operation 6080'. With significant donor pledges, $96.4 \%$ of the amount requested in the WFP-supported operation were met by 


\begin{tabular}{|c|c|c|c|c|}
\hline \multirow[b]{2}{*}{ Region } & \multicolumn{3}{|c|}{ Food security component } & \multirow{2}{*}{$\begin{array}{l}\text { Estimated needy population } \\
\text { in } 2000 / \text { needs }\end{array}$} \\
\hline & Availability & Accessibility & Adequacy & \\
\hline Tigray* & $\begin{array}{l}\text { Decrease in crop production due to } \\
\text { delayed rainfalls. Sorghum failed due } \\
\text { to black beetle infestation }\end{array}$ & $\begin{array}{l}\text { High cereal prices. Low livestock } \\
\text { prices. Increased food aid }\end{array}$ & Stable nutrition status & $\begin{array}{l}1047400 \text { ( } 34 \% \text { of the rural population)/ } \\
\text { infrastructure, food-based approaches, } \\
\text { GFP }\end{array}$ \\
\hline Afart & $\begin{array}{l}40 \% \text { decrease in production of maize, } \\
\text { sorghum and teff due to black beetle } \\
\text { infestation }\end{array}$ & $\begin{array}{l}\text { Improvement in livestock prices due to } \\
\text { military demand. High grain prices }\end{array}$ & $\begin{array}{l}\text { Pervasive childhood malnutrition, even } \\
\text { in families with available and } \\
\text { accessible food. Endemic malaria, } \\
\text { tuberculosis and anaemia }\end{array}$ & $\begin{array}{l}272704 \text { ( } 24 \% \text { of the rural population)/ } \\
\text { nutrition education, provision of grains }\end{array}$ \\
\hline Amhara* & $\begin{array}{l}\text { Teff, barley, wheat, maize, sorghum } \\
\text { and pulses affected by environmental } \\
\text { hazards. Disruption of relief distribution, } \\
\text { inadequate rations and poor targeting }\end{array}$ & $\begin{array}{l}\text { Livestock death in dry months with } \\
\text { distressed/reduced sales of livestock } \\
\text { earlier in the season. Declined } \\
\text { charcoal prices, since more people are } \\
\text { involved in selling it in all zones. } \\
\text { Increased grain prices. Declining wages, } \\
\text { as more people are available for } \\
\text { casual labour }\end{array}$ & $\begin{array}{l}\text { Endemic malaria in lowland. Anticipated } \\
\text { epidemic with rains. In North Gonder } \\
\text { and West Gojjam zones, significant } \\
\text { increase in tuberculosis. In South Wollo, } \\
\text { measles and meningitis outbreaks }\end{array}$ & $\begin{array}{l}2534915 \text { ( } 17 \% \text { of the rural population)/ } \\
\text { food-based approaches, GFP and SFP, } \\
\text { infrastructure, public health measures } \\
\text { and health care }\end{array}$ \\
\hline Oromiya* & $\begin{array}{l}\text { Decrease in usual surplus of maize } \\
\text { affecting inter-regional grain flow with } \\
\text { food security consequences for grain } \\
\text { deficit in neighbouring regions, such } \\
\text { as Amhara }\end{array}$ & $\begin{array}{l}\text { Increased grain prices. Decreased } \\
\text { livestock prices. Average wages } \\
\text { lower due to increased supply of } \\
\text { labour. Low prices of charcoal due to } \\
\text { increased volume in the market. } \\
\text { Decreased coffee production due to } \\
\text { coffee berry disease }\end{array}$ & $\begin{array}{l}\text { High malnutrition rate, especially in } \\
\text { elderly and lactating mothers }\end{array}$ & $\begin{array}{l}1186966 \text { ( } 7 \% \text { of the rural population)/ } \\
\text { food-based approaches, SFP, GFP }\end{array}$ \\
\hline Somali† & $\begin{array}{l}\text { Poor food security associated with } \\
\text { migration to urban areas. Adverse } \\
\text { climatic conditions (dry and saline soils, } \\
\text { not suitable for rain-fed forage/crop } \\
\text { production) }\end{array}$ & $\begin{array}{l}\text { Continuation of poor trade for } \\
\text { pastoralists. Low nutritional status of } \\
\text { livestock. Poor infrastructure affecting } \\
\text { the overall situation }\end{array}$ & $\begin{array}{l}\text { Major outbreaks of bloody diarrhoea and } \\
\text { malnutrition-related diseases. In Doll } \\
\text { Odo and Suftu, malnutrition rate of } \\
26-27 \% \text { (SCF/USA, Sep. 1999) }\end{array}$ & $\begin{array}{l}1321000 \text { ( } 42 \% \text { of the rural population)/ } \\
\text { infrastructure, food-based approaches, } \\
\text { SFP, GFP }\end{array}$ \\
\hline Benishangul-Gumuz* & $\begin{array}{l}\text { Normal production of maize, sorghum } \\
\text { and teff. Mostly virgin land with potential } \\
\text { shifting cultivation }\end{array}$ & $\begin{array}{l}\text { Mixed agriculture, together with crafts } \\
\text { and gold mining, stabilise the region } \\
\text { with favourable food security }\end{array}$ & $\begin{array}{l}\text { No outbreaks reported in the region. } \\
\text { Malaria continues to be endemic }\end{array}$ & $\begin{array}{l}4201 \text { ( } 1 \% \text { of the rural population)/ } \\
\text { infrastructure }\end{array}$ \\
\hline $\begin{array}{l}\text { Southern Nations, } \\
\text { Nationalities and } \\
\text { Peoples Region } \\
(\text { SNNPR) })^{\star}\end{array}$ & $\begin{array}{l}\text { Crops suffer from insufficient rains. } \\
\text { Alarming food availability in Konso }\end{array}$ & $\begin{array}{l}\text { Low grain supply. Increased livestock } \\
\text { supply with decreasing prices. Low pay } \\
\text { for wage labour. High population } \\
\text { pressure in most parts of the region }\end{array}$ & High malnutrition rate & $\begin{array}{l}760500 \text { ( } 7 \% \text { of rural population)/ } \\
\text { food-based approaches, GFP, SFP }\end{array}$ \\
\hline Gambella* & $\begin{array}{l}\text { Chronic poor availability due to crops } \\
\text { damaged by overflowing rivers, weather } \\
\text { irregularities, and lack of access to } \\
\text { markets. Estimated crop production to } \\
\text { cover only half of the annual food needs }\end{array}$ & $\begin{array}{l}\text { Declining purchasing power with } \\
\text { households at risk of food shortages }\end{array}$ & $\begin{array}{l}\text { Acute diarrhoea, most probably due to } \\
\text { contaminated river water }\end{array}$ & $\begin{array}{l}46600(27 \% \text { of the rural population)/ } \\
\text { agriculture assistance, infrastructure }\end{array}$ \\
\hline Hareri* & $\begin{array}{l}\text { Decrease in sorghum (the major crop) } \\
\text { due to rainfall anomalies }\end{array}$ & $\begin{array}{l}\text { Livestock prices within normal range. } \\
\text { Declined crop prices. Improvement } \\
\text { in trade, including chat }\end{array}$ & $\begin{array}{l}\text { No significant health problems and } \\
\text { outbreaks reported. Endemic malaria } \\
\text { in lowland areas }\end{array}$ & $\begin{array}{l}7070(11 \% \text { of the rural population)/ } \\
\text { infrastructure }\end{array}$ \\
\hline Dire Dawa* & Reduced cereal yield & $\begin{array}{l}\text { Increased livestock prices. Declined } \\
\text { charcoal sales (the main source of } \\
\text { income in times of distress) }\end{array}$ & $\begin{array}{l}\text { No indication of severe malnutrition. } \\
\text { Endemic malaria }\end{array}$ & $\begin{array}{l}47459 \text { ( } 53 \% \text { of the rural population)/ } \\
\text { food-based approaches, infrastructure }\end{array}$ \\
\hline
\end{tabular}

${ }^{*}$ Crop-dependent. †Pastoral region. 
the end of the year (minutes from DPPC, WFP and UNICEF). Be that as it may, reports from some regions have shown that this amount did not reach all of the beneficiaries. Instead, rations as small as $3-10 \mathrm{~kg}$ per person per $2-3$ months were provided ${ }^{40}$.

\section{Logistics 1999-2000}

The food aid sent to Ethiopia arrived at major hubs and was distributed by the DPPC. In many areas food deliveries were delayed and irregular, partly due to lack of fuel and trucks ${ }^{40}$. Despite recent improvements in coordination of food distribution, some of the main constraints to distribution were increasing highland transportation rates, competing interests (e.g. use of trucks to transport other commodities) and poor communication and trucking between primary and secondary distribution points ${ }^{40}$.

\section{Targeting the vulnerable with a nutritious diet}

There are two levels of food aid: general feeding programmes (GFPs) and selective feeding programmes. The latter are planned to provide additional food to specific vulnerable groups and embrace two subcategories: supplementary feeding programmes (SFPs) and therapeutic feeding programmes (TFPs) ${ }^{41}$. It has been recommended that GFPs provide food to the affected population as a whole ${ }^{41}$. In Ethiopia the GFP has been targeted to households selected by Peasants' Associations (PAs, the lowest administrative level). The planned food basket for GFP beneficiaries in Ethiopia is presented in Table 2. This theoretical food basket is designed in the framework of WHO/United Nations High Commissioner for Refugees (UNHCR)/WFP recommendations for GFPs $^{41}$. In practice, the general ration for 1999-2000 consisted of only grains and was calculated to supply only $12.5 \mathrm{~kg}$ per person per month ${ }^{42}$. It is a remarkable deviation from the recommended allowances. A partial explanation might be the addition of the internally displaced population to the beneficiaries' lists. In addition, community codes and traditions that call for sharing among all of the needy populations make the targeting unrealistic and could be the cause for dilution of food aid with very limited impact. The current GFP is deficient in macro- and micronutrients and does not fulfil some of other aspects of food aid (e.g. food matched to needs and habits of the recipients) to populations entirely dependent on relief food.

The intended effect of targeted SFPs is to provide caloric and protein supplementation to the GFP (150 g per person per day). The SFP is only a safety net and is not designed to compensate on a long-term basis for an inadequate GFP ${ }^{41}$. In Ethiopia it was provided in Supplementary Feeding Centres (SFCs) and was supposed to target the most vulnerable population. Consequently, since the GFP was not achieved country-wide, the SFP, in many cases, was detached from the GFP, and consequently less effective. Although supplementary distributions were getting underway in most affected areas, the amounts available fell well short of the overall needs. There was no systematic referral methodology to the SFCs. The majority of centres were limited to children under five years. Moreover, parents could either leave their child in the SFC without care for many hours in order to get the general ration, or take the sick child along with them, thus interfering with the SFC care.

\section{Use of monitoring and early warning systems}

The DPPC Early Warning Department produces regular reports, providing data gathered from selected droughtprone districts. These data are focused largely on production indicators including rainfall patterns, animal health and other environmental phenomena, such as

Table 2 Nutritional composition of the current (2000) food basket compared with WHO/UNHCR/WFP recommendation for GFP

\begin{tabular}{|c|c|c|c|c|c|}
\hline \multirow[b]{2}{*}{ Variable } & \multicolumn{2}{|c|}{ Current food basket } & \multicolumn{2}{|c|}{ Recommended food basket } & \multirow{2}{*}{$\begin{array}{c}\% \text { from recommended } \\
\text { basket }\end{array}$} \\
\hline & Composition & $\%$ from energy & Composition & $\%$ from energy & \\
\hline Energy (kcal) & 1520 & & 2100 & & 72 \\
\hline Protein $(\mathrm{g})$ & 47 & 12.4 & 46 & 9 & 102 \\
\hline Fat $(\mathrm{g})$ & 7 & 4.0 & $40-46$ & 20 & 17 \\
\hline Carbohydrate (g) & 315 & 83.6 & 372 & 71 & 85 \\
\hline Vitamin A equivalents $(\mu \mathrm{g})$ & & & 500 & & \\
\hline Vitamin $D(\mu \mathrm{g})$ & & & 3.8 & & \\
\hline Thiamine (mg) & 1.6 & & 0.9 & & 177 \\
\hline Riboflavin (mg) & 0.415 & & 1.4 & & 30 \\
\hline Niacin equivalents $(\mu \mathrm{g})$ & 18.2 & & 12.0 & & 151 \\
\hline Folic acid $(\mu \mathrm{g})$ & & & 160 & & \\
\hline Vitamin $B_{12}(\mu \mathrm{g})$ & 0 & & 0.9 & & 0 \\
\hline Vitamin C (mg) & 0 & & 28 & & 0 \\
\hline lodine $(\mu \mathrm{g})$ & & & 150 & & \\
\hline Iron (mg) & 19 & & 22 & & 86 \\
\hline Calcium (mg) & 133 & & 500 & & 27 \\
\hline
\end{tabular}

Source: USDA Agriculture Handbook No. 8/20, Composition of foods: Cereal, grains and pasta, 1989. 
flooding and hailstorms. Another important source is the Save the Children Fund - United Kingdom (SCF-UK) Nutrition Surveillance Project (NSP) and special emergency nutrition monitoring teams (NMTs) composed of SCF-UK and DPPC staff. This body conducts monthly nutrition surveys that are confined to some droughtaffected woredas (level of administration below a region). Survey findings are distributed among major government, UN, bilateral and non-government organisations. Whereas the purpose of the NSP is to provide early warning of acute food insecurity through a long-term monitoring strategy, the aim of NMT activity is to inform specific short-term relief operations. No other comprehensive nutritional surveillance mechanisms are in place dedicated to other drought-affected areas. In some cases, individual NGOs, such as MSF-Holland in Konso, conducted local nutrition surveys in co-ordination with local health and relief departments. However, in many areas, lack of zonal and district capacity in nutrition surveillance had limited the mobilisation of the necessary monitoring mechanisms. It seems that the current early warning data did not sufficiently monitor FNS indicators and coping mechanisms.

\section{Discussion}

The food security situation in Ethiopia has been extremely precarious for some eight million people due to the combination of environmental, socio-political and developmental instabilities. Drought is a recurrent feature of the climate of Ethiopia, and its effects are severe since the agriculture is predominantly rain-fed. Under the existing fragile circumstances in Ethiopia, the drought has taken even a greater toll. Lack of food in the household imposes inordinate strains on the daily burdens of its members. Coping mechanisms have been eroded in many households due to significant depletion of assets and displacement.

Food aid can make a meaningful contribution when the presence of famine is identified and reported on time. Expanded and improved early warning systems can predict and direct the preparedness for emergencies. There are abundant data sources on the nutritional status of Ethiopian citizens. The professionalism that is required to handle this issue is present, though much of it has not been used for this purpose. Over the last five years, resources and capacities in early warning systems have been strengthened at national and regional levels, drawing on bilateral aid, UN and NGO support in this area. However, the present crisis demonstrates that emergency nutrition surveillance and emergency response lacked timely response, harmonisation and co-ordination. In this regard, food, nutrition and health can be looked at as a single unit with diverse multisectoral inputs and outputs.

There are at least three predictable famine indicators for Ethiopian households: (1) deterioration of the land status, i.e. decline in soil fertility and decrease in land size; (2) poor crop performance; and (3) deterioration of alternative income sources. When these factors are triggered by drought or pest infestation, the household is at risk. This calls for a centralised data collection with emphasis on early warning indicators supported by effective mapping, rather than on late indicators, such as anthropometric measurements. The development of a 'Food and Nutrition Geographical Information System' is one way to achieve it (Table 3). A dedicated capacity (from the centre to the woredas) is required in order to plot the global picture of malnutrition, to co-ordinate and monitor required interventions. A clear dissemination chain, with description of the active responsibilities of each level, may ensure efficacy.

In general, the culinary and eating habits in each of the regions are homogeneous and non-diversified, mainly based on cereals and pulses. This sort of diet may result in kwashiorkor, stunted growth and MNDs. Also, since iodised salt is unavailable, and seafood is not generally consumed, the very high prevalence of IDD is not surprising. The food aid rations have not met the needs of the vulnerable populations for macro- and micronutrients. Food aid to Ethiopia has been based on wheat, substituting the customary consumption of teff. This can contribute even further to MNDs, such as iron.

Food aid could be meaningful if the food basket is expanded to provide the recommended 'Food Based Food Relief', with $15 \mathrm{~kg}$ of cereals, legumes, oil, salt and sugar per person per month. Considering the current inability to fortify salt with iodine in Ethiopia, and the instability of oil consumption, it seems that the most stable vehicle for fortification is wheat provided by food aid agencies. To eliminate the common MNDs, it is recommended to fortify the wheat flour with iron, iodine, calcium, zinc and vitamins $\mathrm{A}, \mathrm{B}_{1}, \mathrm{~B}_{2}$, niacin and folate. This is crucial for the part of the population that will remain in a vulnerable state and for families who totally depend on the GFP. It is suggested that the fortification programme be planned with the federal and local health authorities and DPPC, and linked with other federal programmes. Since overfortification may be harmful, the dosage of the fortificants should be carefully determined. Assessment of the effect of the fortification programme should include monitoring of macro- and micronutrient deficiencies, culinary habits, consumption and selling patterns.

Moreover, it is recommended to use the wheat fortification project in conjunction with other NGO and UN agency projects. Some of the examples are dissemination of personal hygiene materials (e.g. soap), singledose de-worming medication, provision of vitamin $\mathrm{A}$ and SFP in healthcare centres and schools, and development of school gardens to produce vegetables and fruit to be consumed by the pupils. Other projects include women's education, establishment of health centres combined with SFP, growth monitoring in schools with referral to health 
Table 3 A suggested framework for food and nutrition key indicators in a geographical information system

\begin{tabular}{|c|c|c|c|}
\hline Food availability & Food accessibility & $\begin{array}{c}\text { Food and nutrition } \\
\text { adequacy }\end{array}$ & Health and nutrition status \\
\hline $\begin{array}{l}\text { - Food production, } \\
\text { food distribution } \\
\text { - Weather } \\
\text { - Early crop condition } \\
\text { (pest and disease) } \\
\text { - Harvest, expected yield } \\
\text { - Food balance sheet; } \\
\text { dietary energy supply } \\
\text { - Alternative food sources } \\
\text { - Policy affecting production } \\
\text { - Political instability } \\
\text { - Rainfall } \\
\text { - Irrigation }\end{array}$ & $\begin{array}{l}\text { - Household income and } \\
\text { purchasing power } \\
\text { - Price to income ratio } \\
\text { - Price of common staples } \\
\text { - Price distribution over the } \\
\text { year } \\
\text { - Access to safe water and to } \\
\text { adequate sanitation } \\
\text { - Policies affecting rations and } \\
\text { subsidies } \\
\text { - Transportation and roads } \\
\text { condition }\end{array}$ & $\begin{array}{l}\text { - Food frequency of key items } \\
\text { - Frequmption } \\
\text { shortages of items typical to } \\
\text { - Average energy intake } \\
\text { - Average food intake of major } \\
\text { food groups } \\
\text { - Daily per capita macronutrient } \\
\text { intake } \\
\text { - Percentage of energy from fat } \\
\text { - Percentage of protein from } \\
\text { - Perimal source } \\
\text { - Percentage of households } \\
\text { - Prevalence of exclusive } \\
\text { breast-feeding for six months } \\
\text { - Prevalence of infants } 6-12 \text { months } \\
\text { breast-fed and types of } \\
\text { complementary feeding } \\
\text { - Prevalence of infants at } 20-23 \\
\text { months still breast-fed } \\
\text { - Perception of adequacy (hunger) } \\
\text { - Crop quality }\end{array}$ & $\begin{array}{l}\text { - Infant mortality rate } \\
\text { - Under five mortality rate } \\
\text { - Maternal mortality rate } \\
\text { - Immunisation rate for measles, } \\
\text { tuberculosis, diphtheria, tetanus } \\
\text { and poliomyelitis } \\
\text { - HIV/AIDS, tuberculosis and } \\
\text { sexually transmitted } \\
\text { diseases } \\
\text { - Enteric infections } \\
\text { - Iron-deficiency anaemia rate } \\
\text { - Goitre rate } \\
\text { Infants and children: } \\
\text { - Low birth weight } \\
\text { - Weight-for-height (Z-scores) } \\
\text { - Und BMl for age } \\
\text { - Stunting } \\
\text { - Wasting } \\
\text { Adults: } \\
\text { - BMI < } 20 \text { and under } 18.5 \mathrm{~kg} \mathrm{~m}^{-2} \\
\text { - Sitting height/stature } \\
\text { - Labour productivity }\end{array}$ \\
\hline
\end{tabular}


staff for further evaluation, and nutritional and medical treatment for those below $-2 Z$-score. Exclusive breastfeeding promotion until six months of age followed by the addition of complementary feeding (including boiled water, fortified flour, etc.), as well as use of oral rehydration solutions (ORS) during diarrhoea in infancy and childhood, should all be part of nutritional and health education programmes.

The scarcity of effective healthcare services and the lack of laboratories and professional staff call for concentrated efforts and holistic approaches by all of the sectors concerned. The logistic problem should be treated with the urgency it deserves. It could be that a shift from a perbeneficiary focus to that of a geographic area, targeting on worst-affected communities, would make the process easier.

The FNS analyses in the regions show that food aid alone cannot meet the increasing requirements. A sustainable approach to alleviate famine should link food emergency with maintenance and development of the natural resources, and promotion of the capacity of farmers to solve the problems they face. The African Highland Ecoregional Programme is actively involved in farmers' capacity building through farmers' participatory natural resource management research in east African Highlands, including Ethiopia, and could serve as a model for such interventions.

\section{Conclusions and policy implications}

Despite a broad response to the Ethiopian government appeals for food aid by the UN organisations, NGOs and bilaterals, the population in need is larger than anticipated and therefore the food aid is inadequate. The need is not only in quantity but also in quality. The food basket needs to be expanded and also to include a variety of food-based alternatives. The wheat provided should be fortified and complemented with pulses and oil. The current food aid programme, led by WFP, has assisted in building local capacity to monitor and cope with emergencies more effectively. It certainly saves lives, but the search is still on for appropriate long-term solutions that build bulwarks against a crisis, and minimise the need for food aid or find ways of using it more constructively when it is required.

The formulation of a national food and nutrition policy by the Ethiopian government is a challenging task. If fulfilled, it could lead to harmonised, co-ordinated and sustainable improvements in nutritional well-being and human and social development. It is recognised that the agricultural and industrial sectors, and not the health sector, have the responsibility for the food chain. Also, there are different levels of possible interventions to overcome the famine: food aid, agricultural, environmental and healthcare developments and other infrastructure investments for short-, medium- and long-term achievements. Therefore, concentrated and holistic efforts by all concerned sectors in the country are needed. There is a need for policy improvement to ensure the development of refined methodologies for targeting FNS in the different zones. An integrated and comprehensive approach of the policy will be centred on the mobilisation of health, environment, education and agriculture professionals, the public and the private sector. This could expand the focus to include both relief efforts and field management procedures during famine as well as underlying factors leading to famine.

\section{Acknowledgements}

Special thanks to Hae-Won Park and Berthelomiyos Tesfaye from WFP and Getahun from DPPC Bahir-Dar for their patience and guidance, and to Zadeka from WFP for driving us everywhere. Gratitude to all the professionals who shared their experience and knowledge, especially to Dr Charles Teller from DPPC/USAID and to the Ethiopians who let us into their homes and their lives. We would like to thank Mr Ariel Kerem, the Israeli Ambassador to Ethiopia, Dr Yossi Baratz from MASHAV and the Ministries of Foreign Affairs and Health of Israel for their recognition of the importance of nutrition and their assistance in all the stages of the consultations.

\section{References}

1 United Nations Development Programme (UNDP). Human Development Report Ethiopia. New York: UNDP, 2001.

2 de Onis M, Monteiro C, Akr J, Clugston G. The Worldwide Magnitude of Protein-energy Malnutrition: An Overview from the WHO Global Database on Child Growth. Geneva: World Health Organization, 1997.

3 World Food Programme (WFP). Nutrition Consultancy Report on WFP EMOP 6143 and EMOP 6080. Addis Ababa: WFP, 1999.

4 World Health Organization (WHO). World Health Report 2000. Geneva: WHO, 2000.

5 United Nations Children's Fund (UNICEF). State of the World's Children 2001. New York: UNICEF, 2001.

6 The Office and Housing Census Commission of the Central Statistical Authority. Ethiopia Demographic and Health Survey 2000. Addis Ababa: Central Statistical Authority, 2000 .

7 Census Commission of the Central Statistical Authority. The Population and Housing Census of Ethiopia: Result at Country Level. Vol. 1. Addis Ababa: Central Statistical Authority, 1998.

8 Unites States Agency for International Development. Country Health Statistics Profile for Ethiopia. Arlington, VA: Centre for International Health Information (CIHI), 1999.

9 United Nations Children's Fund (UNICEF). Country Statistics for Ethiopia. New York: UNICEF, 1999.

10 Joint UN Programme on HIV/AIDS (UNAIDS)/World Health Organization (WHO). Epidemiological Fact Sheet on HIV/AIDS and Sexually Transmitted Infections 2000 Update. Geneva: UNAIDS, 2000.

11 Semba RD, Tang AM. Micronutrients and the pathogenesis of human immunodeficiency virus infection. Br. J. Nutr. 1999; 3: 181-9.

12 National Population Office. Ethiopian Population and 
Development Situation Statistical Description. Addis Ababa: Ethiopia National Population Office, 1996.

13 Amede T. Yield gain and risk minimisation in maize (Zea mays) through cultivar mixtures in the semi-arid zones of the Rift-valley in Ethiopia. Exp. Agric. 1995; 31: 161-8.

14 World Bank. Entering the 21st Century. World Development Report 1999/2000. New York: Oxford University Press, 2000.

15 Diribe G. Economy at the Crossroads: Famine and Food Security in Rural Ethiopia. Addis Ababa: Commercial Printing Enterprise, 1995; 390.

16 Salama P, Assefa F, Talley L, Spiegel P, van Der Veen A, Gotway CA. Malnutrition, measles, mortality, and the humanitarian response during a famine in Ehiopia. J. Am. Med. Assoc. 2001; 286: 563-71.

17 United Nations Children's Fund (UNICEF) Ethiopia. Review of Drought Nutrition Response. Addis Ababa: UNICEF, November 1999.

18 Food and Agriculture Organization (FAO). Energy and Protein Requirements. Report of a Joint FAO/WHO/UNU Expert Consultation. Rome: FAO, 1985.

19 National Academy of Science Committee on Nutrition. Estimated Mean Per Capita Energy Requirements for Planning Emergency Food Aid Rations. Washington, DC: National Academy Press, 1995.

20 Food and Agriculture Organization (FAO). Food Balance Sheet for Ethiopia. Rome: FAO, 1998.

21 Pastore G, Branca F, Demissie T, Ferro-Luzzi A. Seasonal energy stress in an Ethiopian rural community: an analysis of the impact at the household level. Eur. J. Clin. Nutr. 1993; 47: 851-62

22 Ethiopian Nutrition Institute (ENI). National Nutritional Surveillance Programme Report. Addis Ababa: ENI, 1980.

23 United Nations Children's Fund (UNICEF). State of the World's Children Report. New York: UNICEF, 1993.

24 Office of the United Nations High Commissioner for Refugees (UNHCR)/World Food Programme (WFP). Guidelines for Estimating Food and Nutritional Needs in Emergencies. Geneva: UNHCR/WFP, 1997.

25 Central Statistics Authority. Household Income, Consumption and Welfare Monitoring Survey Report. Addis Ababa: Central Statistics Authority, 1996.

26 Lindtjorn B, Alemu T. Intra-household correlations of nutritional status in rural Ethiopia. Int. J. Epidemiol. 1997; 26: $160-5$.
27 Ferro-Luzzi A, Scaccini C, Taffesse S, Abera B, Emeke T. Seasonal energy deficiency in Ethiopian rural women. Eur. J. Clin. Nutr. 1990; 44(Suppl. 1): 7-18.

28 Haidar J, Demissie T. Nutrition situation in Ethiopia. S. Afr. J. Clin. Nutr. 1998; 89: 181-3.

29 Demissie T. Food cravings, aversions and taboos during pregnancy and their significance to maternal nutrition. Masters thesis, Nairobi University, Nairobi, 1996.

30 Postumus S. Report on Nutritional Needs of Children in Ethiopia. FAO Reports. Rome: Food and Agriculture Organization, 1958

31 Wolde-Gebriel Z, Demeke T, West CE. Xerophthalmia in Ethiopia: a nation-wide ophthalomological, biochemical and anthropometric survey. Eur. J. Clin. Nutr. 1991; 45: 469-78.

32 Haidar J, Demissie T. Malnutrition and xerophthalmia in rural communities of Ethiopia. E. Afr. Med. J. 1999; 76 : $590-3$

33 Ethiopia Nutrition Institute (ENI). Goiter Survey. Addis Ababa: ENI, 1981

34 Hovander Y. Haematological investigations in Ethiopia. Acta Med. Scand. 1968; 494(Suppl.): 1-74.

35 Tedla S, Jemaneh L. Distribution of Ancylostoma duodenale and Necator americanus in Ethiopia. Ethiop. Med. J. 1985; 23: $149-58$

36 Umeta M, West CE, Haidar J, Deurenberg P, Hautvast JG. Zinc supplementation and stunted infants in Ethiopia: a randomised controlled trial. Lancet 2000; 355: 2021-6.

37 Gibson RS. Zinc supplementation for infants. Lancet 2000; 355: 2008-9.

38 Food and Agriculture Organization (FAO)/World Health Organization (WHO). International Conference on Nutrition. Rome: FAO, 1992.

39 Food and Agriculture Organization (FAO)/World Health Organization (WHO). Crop and Food Supply Assessment Mission to Ethiopia 26 January 2000. FAO Global Information and Early Warning System on Food and Agriculture Special Report. Rome: FAO, 2000.

40 Save the Children Fund - UK (SCF-UK). International Surveillance Programme - Ethiopia: NSP Results MarchJune 2000. Addis Ababa: SCF-UK, 2000.

41 World Health Organization (WHO). The Management of Nutrition in Major Emergencies. Geneva: WHO, 2000.

42 World Food Programme (WFP). Report on the Situation Report in the Somali Region. Gode: WFP, 2000. 